\title{
健康診断の成績と心筋梗塞・脳出血疾患との 関係について
}

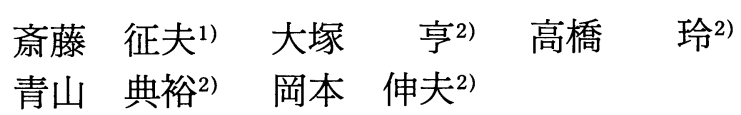

\section{目的}

人口の高齢化, ライフスタイルの変化などによ って, わが国の成人病は急増しており, 悪性新生 物, 心臟疾患, 脳血管疾患のいわゆる三大成人病 での死亡率は，全死亡の約 $60 \%$ を占めている ${ }^{1)}$

これらの成人病対策の一つとして, 成人病健診 をはじめとする健康診断が広く行われている。平 成 4 年の成人を対象としての健康診断受診者数 は，職域や地域を合わせれば数千万人となってお り，この人数は，今後増加することはあっても減 少することはないであろう2,3)。

胃癌, 子宮癌などの悪性新生物は, 健康診断に よって早期発見・早期治療が行われ，これらの死 亡率は減少している ${ }^{1,4)}$ 。

一方, 成人の心臓疾患の代表的疾患である心筋 梗塞や脳血管疾患は, 疾患の特性からいって, 悪 性新生物のように健康診断によって発見されるこ とはないと言っても過言ではない。そして，心筋 梗塞や脳血管疾患は, 健康診断成績の正常者から 健康診断受診後に発症することがあり，このよう な場合，受診者が健康診断そのものに対し疑問を 抱くことにもなる。

本研究は, 心筋梗塞, 脳出血疾患の予知・予防 を目的として, 健康診断受診者のうち, 受診後 1 年以内に心筋梗塞, 脳出血疾患にて死亡した症

Relationships Between Results of Medical Examination and Diseases of Myocardial Infarction and Cerebral Bleeding
1）愛知医科大学公衆衛生学
2) 中部健康管理センター

例を対象にして，健康診断の成績と疾患との関係 を調べたものである。

\section{対象と方法}

1. 対象は, 平成 4 年 4 月から平成 7 年 3 月ま での 3 年間に, 名古屋市内にある C 健康管理セン ターの成人病健診を受診した者のうち, 健康診断 受診後 1 年以内に心筋梗塞, 脳出血疾患を発症し て死亡した心筋梗塞 14 例, 脳出血 11 例で, 表 1 , 表 2 のごとくである。

なお，女性は症例が少なく検討できなかったた め, 男性のみを対象とした。

成人病健診受診者は, 愛知県を中心に中部 7 県 の土木建築労働者で, 会社の定期健康診断として, $\mathrm{C}$ 健康管理センターの成人病健診を受診した 46,316 人 (男性) で，その年代分布は表 3 のごと くである。

C 健康管理センターは, 保健組合の直営機関で あり,この保健組合では, 組合員およびその家族 が死亡した場合，見舞金が支給される。そのため， 死亡時には死亡診断書が保健組合に提出される。 本研究の対象者はこの制度によった。この時, 家 族には死亡した医療機関に病名および診断方法の 調査の了解を求め承諾を得た。心筋梗塞の診断 は, 心電図, 心エコー, 冠動脈撮影, 血清生化学 検査にて, 脳出血のそれは, MRI 等にて確認され たものである。

2. 健康診断の成績と心筋梗塞, 脳出血疾患との 検討は, 肥満度, 血圧, 総コレステロール(TC), 中性脂肪 (TG), high-density-lipoprotein-コレス テロール (HDL-C), 空腹時血糖 (FBS), 尿酸 
表 1 健康診断の成績と心筋梗塞症例

\begin{tabular}{|c|c|c|c|c|c|c|c|c|c|c|c|c|c|}
\hline & \multirow{2}{*}{$\begin{array}{l}\text { 年齢 } \\
\text { (歳) }\end{array}$} & \multirow{2}{*}{\begin{tabular}{|l} 
契煙 \\
本/日 \\
\end{tabular}} & \multirow{2}{*}{$\begin{array}{c}\text { 毎日飲酒量 } \\
\mathrm{g} / \text { 日 }\end{array}$} & \multirow{2}{*}{$\begin{array}{c}\text { 肥満度 } \\
(\%)\end{array}$} & \multirow{2}{*}{$\begin{array}{c}\text { 血圧 } \\
\mathrm{mmHg}\end{array}$} & \multicolumn{2}{|c|}{ 心電図 } & \multirow{2}{*}{$\begin{array}{c}\text { 総コレステロール } \\
\mathrm{mg} / \mathrm{d} l\end{array}$} & \multirow{2}{*}{$\begin{array}{c}\text { 中性脂肪 } \\
\mathrm{mg} / \mathrm{d} l\end{array}$} & \multirow{2}{*}{$\begin{array}{c}\text { HDL-コレステロール } \\
\mathrm{mg} / \mathrm{d} l\end{array}$} & \multirow{2}{*}{\begin{tabular}{|c} 
空腹時血糖 \\
$\mathrm{mg} / \mathrm{d} l$
\end{tabular}} & \multirow{2}{*}{\begin{tabular}{|c|} 
尿酸 \\
$\mathrm{mg} / \mathrm{d} l$
\end{tabular}} & \multirow{2}{*}{ 現病歴 } \\
\hline & & & & & & 安静 & \begin{tabular}{|l|} 
負荷 \\
\end{tabular} & & & & & & \\
\hline No 1 & 36 & 40 & 23 & \begin{tabular}{|l|}
111.3 \\
\end{tabular} & $120 / 68$ & WNL & $(-)$ & 157 & 113 & 34 & 92 & 5.8 & \\
\hline 2 & 46 & 30 & 23 & 100.4 & $113 / 64$ & WNL & $(+)$ & 133 & 62 & 25 & 87 & 7.0 & \\
\hline 3 & 51 & 40 & 0 & 98.5 & $120 / 60$ & WNL & $(-)$ & 200 & 182 & 44 & 96 & 4.6 & \\
\hline 4 & 55 & 15 & 23 & \begin{tabular}{|l|}
112.6 \\
\end{tabular} & $160 / 104$ & ST-T $\downarrow$ & 7 & 273 & 216 & 59 & 107 & 4.1 & 狭心症 \\
\hline 5 & 56 & 30 & 28 & 119.4 & $128 / 78$ & WNL & $(+)$ & 205 & 142 & 31 & 92 & 3.6 & \\
\hline 6 & 57 & 30 & 87 & 105.5 & $140 / 85$ & WNL & $(+)$ & 170 & 104 & 43 & 88 & 5.8 & \\
\hline 7 & 58 & 0 & 46 & 120.9 & $150 / 98$ & WNL & $(+)$ & 179 & 278 & 49 & 106 & 4.5 & \\
\hline 8 & 58 & $?$ & ? & 97.9 & $158 / 84$ & \begin{tabular}{|l|}
$\mathrm{LVH}$ \\
\end{tabular} & $(+)$ & 134 & 80 & 69 & 95 & 5.3 & \\
\hline 9 & 60 & 30 & 58 & 86.2 & $129 / 73$ & WNL & $(-)$ & 174 & 89 & 59 & 93 & 5.2 & \\
\hline 10 & 60 & 20 & 58 & 100.1 & $162 / 108$ & LVH & $(+)$ & 216 & 147 & 50 & 93 & 7.7 & \\
\hline 11 & 63 & 30 & 58 & 95.4 & $140 / 72$ & WNL & $(+)$ & 233 & 78 & 69 & 113 & 5.2 & \\
\hline 12 & 63 & 0 & 57 & 92.8 & $170 / 104$ & WNL & $(+)$ & 170 & 47 & 52 & 93 & 4.1 & \\
\hline 13 & 64 & 20 & 0 & 102.4 & $155 / 75$ & WNL & $(+)$ & 196 & 121 & 60 & 120 & 3.6 & 糖尿病 \\
\hline 14 & 66 & 40 & 0 & 100.4 & \begin{tabular}{|l|}
$113 / 64$ \\
\end{tabular} & ST-T $\downarrow$ & 1 & 133 & 62 & 25 & 87 & 7.0 & \\
\hline
\end{tabular}

表 2 健康診断の成績と脳出血症例

\begin{tabular}{|c|c|c|c|c|c|c|c|c|c|c|c|c|}
\hline & \begin{tabular}{|l|} 
年齢 \\
(歳)
\end{tabular} & $\begin{array}{l}\text { 喫煙 } \\
\text { 本/日 } \\
\end{array}$ & \begin{tabular}{|c} 
毎日飲酒量 \\
$\mathrm{g} /$ 日
\end{tabular} & \begin{tabular}{|c} 
肥満度 \\
$(\%)$
\end{tabular} & $\begin{array}{c}\text { 血圧 } \\
\mathrm{mmHg}\end{array}$ & $\begin{array}{l}\text { 心電図 } \\
\text { 安 静 }\end{array}$ & $\begin{array}{c}\text { 総コレステロール } \\
\mathrm{mg} / \mathrm{d} l\end{array}$ & \begin{tabular}{|c} 
中性脂肪 \\
$\mathrm{mg} / \mathrm{d} l$
\end{tabular} & \begin{tabular}{|c|}
$\mathrm{HDL}$-コレステロール \\
$\mathrm{mg} / \mathrm{d} l$ \\
\end{tabular} & \begin{tabular}{|c} 
空腹時血糖 \\
$\mathrm{mg} / \mathrm{d} l$
\end{tabular} & \begin{tabular}{|c|} 
尿酸 \\
$\mathrm{mg} / \mathrm{d} l$
\end{tabular} & 現病歴 \\
\hline No 1 & 40 & 30 & 81 & 110.9 & $197 / 113$ & LVH & 299 & 689 & 53 & 104 & 9.7 & \\
\hline 2 & 49 & 40 & 60 & \begin{tabular}{|l|l}
113.8 \\
\end{tabular} & $126 / 82$ & WNL & 226 & 141 & 30 & 88 & 8.7 & \\
\hline 3 & 50 & $?$ & $?$ & 111.2 & $166 / 106$ & WNL & 194 & 107 & 46 & 130 & 4.7 & 糖尿病 \\
\hline 4 & 51 & 40 & 0 & \begin{tabular}{|l|}
122.9 \\
\end{tabular} & $156 / 106$ & LVH & 245 & 150 & 23 & 95 & 7.3 & \\
\hline 5 & 52 & 30 & 0 & 127.7 & $124 / 84$ & WNL & 210 & 100 & 70 & 98 & 8.7 & \\
\hline 6 & 54 & 20 & 58 & 121.3 & $176 / 110$ & LVH & 160 & 202 & 41 & 228 & 6.8 & 糖尿病 \\
\hline 7 & 55 & $?$ & ? & 110.7 & $146 / 86$ & ST-T $\downarrow$ & 163 & 74 & 53 & 182 & 3.9 & 糖尿病 \\
\hline 8 & 61 & 15 & 25 & 93.3 & $190 / 100$ & LVH & 139 & 76 & 53 & 97 & 4.6 & \\
\hline 9 & 64 & 30 & 44 & 113.1 & $158 / 90$ & WNL & 209 & 117 & 56 & 86 & 5.9 & \\
\hline 10 & 66 & 5 & 44 & 122.6 & $176 / 108$ & LVH & 189 & 100 & 56 & 203 & 10.0 & 糖尿病 \\
\hline 11 & 67 & 40 & 0 & 118.1 & $160 / 110$ & LVH & 173 & 296 & 49 & 102 & 5.2 & \\
\hline
\end{tabular}

表 3 成人病健診および運動負荷心電図の受診者数

\begin{tabular}{|c|c|c|c|c|c|c|c|c|}
\hline & \multicolumn{2}{|c|}{ 平成 4 年 4 月 平成 5 年 3 月 } & \multicolumn{2}{|c|}{ 平成 5 年 4 月 平成 6 年 3 月 } & \multicolumn{2}{|c|}{ 平成 6 年 4 月 平成 7 年 3 月 } & \multicolumn{2}{|c|}{ 平成 4 年 4 月 平成 7 年 3 月 } \\
\hline & 受診者数(人) & 運動負荷 (人) & 受診者数 & 運動負荷 & 受診者数 & 運動負荷 & 受診者数 & 運動負荷 \\
\hline $\begin{array}{c}20 \sim 29 \\
\text { (歳) }\end{array}$ & 2272 & 45 & 2450 & 73 & 2849 & 71 & 7571 & 189 \\
\hline $30 \sim 39$ & 3043 & 213 & 2628 & 158 & 2861 & 258 & 8532 & 629 \\
\hline $40 \sim 49$ & 5270 & 949 & 4634 & 927 & 5304 & 1008 & 15208 & 2884 \\
\hline $50 \sim 59$ & 3591 & 862 & 3473 & 729 & 4143 & 1035 & 11207 & 2626 \\
\hline $60 \sim 69$ & 1268 & 126 & 1229 & 209 & 1301 & 247 & 3798 & 582 \\
\hline $20 \sim 69$ & 15444 & 2195 & 14414 & 2096 & 16458 & 2619 & 46316 & 6910 \\
\hline
\end{tabular}


(BUA), 心電図 (ECG), さらには, 現病歴・喫 煙・飲酒状況にて行った。

なお，血圧は，WHO の血圧判定基準によって， 140/90 未満を正常, 160/95 以上を高血圧, それ以 外を境界血圧とした ${ }^{5)}$ 。

$\mathrm{TC}$ は日本動脈硬化学会の基準によって, 219 $\mathrm{mg} / \mathrm{d} l$ 以下を, TG は $150 \mathrm{mg} / \mathrm{d} l$ 以下を正常と し, HDL-C は $40 \mathrm{mg} / \mathrm{d} l$ 以上を正常, FBS は 109 $\mathrm{mg} / \mathrm{d} l$ 以下を, BUA は $7.0 \mathrm{mg} / \mathrm{d} l$ 以下を正常と した。

安静時の心電図は, 健康診断受診者の全員が行 っているが, 運動負荷心電図は希望者のみである ため, 心筋梗塞症例は安静・運動負荷心電図をと もに行っている者のみとし, 運動負荷心電図受診 者は表 3 のごとくである。

心電図による左室肥大とは, $\mathrm{V}_{5}\left(\mathrm{~V}_{6}\right)$ の $\mathrm{R}>26$ $\mathrm{mmV}, \mathrm{Rv}_{5}\left(\mathrm{v}_{6}\right)+\mathrm{Sv}_{1} \geqq 40 \mathrm{mmV}$ あるいは $\mathrm{a}_{\mathrm{L}}$ の $\mathrm{R}>12 \mathrm{mmV}$ の場合, すなわち, ミネソタコードの 3-1 であり, ST-T の変化とは, ST の下降と陰性 T波で，ミネソタコードの 4 と 5-1，5-2 である。

運動負荷心電図は, 性・年齢・体重別によって 定められた回数を 3 分で階段を昇降するダブルマ スターで行い, ST の $0.5 \mathrm{mmV}$ 以上の低下, T 波 の逆転を認めた場合に陽性とした。

現病歴, 喫煙 - 飲酒状況の調査は, 健康診断時 に自記式のアンケートにて行い, 現病歴は医師が, 喫煙と飲酒は保健婦が確認した。

そして, 喫煙はその有無と 1 日喫煙本数を, 飲 酒は飲酒頻度とともに, エタノール換算での 1 日 飲酒量を調べた。
肥満度は, 体重 $(\mathrm{kg}) /($ 身長 -100$) \times 0.9$ で算出 されるブローカーの挂変法にて行った。

\section{結 果}

\section{1. 健康診断の成績と心筋梗塞}

表 1 と表 4 は, 健康診断の成績と心筋梗塞との 関係を示したものである。

年齢は, 36 歳から 66 歳までの 14 人で, 30 歳代 1 人, 40 歳代 1 人, 50 歳代 6 人, 60 歳代 6 人であ った。

喫煙・飲酒状況では, 喫煙者は 13 人のうち 11 人 (84.6\%) で, 平均 1 日喫煙本数は 29.5 本であっ た。飲酒は, 毎日飲酒者が 13 人のうち 10 人 $(76.9 \%)$ で, 平均 1 日飲酒量は $46.1 \mathrm{~g}$ であった。 肥満度は, 平均 $103.2 \%$ で, $120 \%$ 以上の肥満者 は 14 人のうち 1 人であった。

血圧では, 正常血圧者は 14 人のうち 8 人 $(57.1$ $\%)$, 境界血圧者は 14 人のうち 2 人 $(14.3 \%)$, 高 血圧者は 14 人のうち 4 人 $(28.6 \%)$ であった。

安静時の心電図では, ST-T の変化を認めた者 は 14 人のうち 2 人 $(14.3 \%)$ で, 運動負荷後の心 電図では, 安静時心電図で ST-T の変化を認めな かった 12 人のうち 8 人 (66.7\%) に ST-T の異常 が認められた。

血清生化学検査では, 高 TC 值者は 14 人のうち 3 人 $(21.4 \%)$, 高 TG 值者は 14 人のうち 3 人 $(21.4 \%)$, 低 HDL - C 值者は 14 人のうち 4 人 $(28.6 \%)$, 高 FBS 值者は 14 人のうち 2 人 $(14.3$ \%)で, 糖尿病者は 1 名であった。高 BUA 值者は 14 人のうち 1 人 $(7.1 \%)$ であった。

表 4 健康診断の成績と心筋梗塞

\begin{tabular}{|c|c|c|c|c|c|c|c|c|c|c|}
\hline \multicolumn{2}{|c|}{ 喫 煙 } & \multicolumn{2}{|c|}{ 毎日飲酒 } & \multicolumn{2}{|c|}{ 肥満度 } & \multicolumn{3}{|c|}{ 血 圧 } & \multicolumn{2}{|c|}{ 心電図 } \\
\hline 有 & 本/日 & 有 & $\mathrm{g} /$ 日 & 平均 & $\begin{array}{r}120 \% \\
\text { 以上 } \\
\end{array}$ & 正常 & 境界 & 高血圧 & \begin{tabular}{|c|} 
安静 \\
ST-T $\downarrow$ \\
\end{tabular} & $\begin{array}{l}\text { 負荷 } \\
\text { 陽性 }\end{array}$ \\
\hline $\begin{array}{c}11 / 13 \\
84.6 \%\end{array}$ & 29.5 & \begin{tabular}{c|}
$10 / 13$ \\
$76.9 \%$
\end{tabular} & 46.1 & $103.2 \%$ & $\begin{array}{c}1 / 14 \\
7.1 \% \\
\end{array}$ & \begin{tabular}{|c|}
$8 / 14$ \\
$57.1 \%$ \\
\end{tabular} & \begin{tabular}{|c|}
$2 / 14$ \\
$14.3 \%$ \\
\end{tabular} & \begin{tabular}{|c|}
$4 / 14$ \\
$28.6 \%$ \\
\end{tabular} & $\begin{array}{c}2 / 14 \\
14.3 \% \\
\end{array}$ & $\begin{array}{c}9 / 12 \\
75.0 \% \\
\end{array}$ \\
\hline
\end{tabular}

\begin{tabular}{|c|c|c|c|c|c|c|c|c|c|}
\hline \multicolumn{2}{|c|}{ 総コレステロール } & \multicolumn{2}{|c|}{ 中性脂肪 } & \multicolumn{2}{|c|}{ HDL-コレステロール } & \multicolumn{2}{|c|}{ 空腹時血糖 } & \multicolumn{2}{|c|}{ 尿 酸 } \\
\hline $\begin{array}{c}\text { 平均 } \\
\mathrm{mg} / \mathrm{d} l\end{array}$ & 異常者 & $\begin{array}{c}\text { 平均 } \\
\mathrm{mg} / \mathrm{d} l\end{array}$ & 異常者 & $\begin{array}{c}\text { 平均 } \\
\mathrm{mg} / \mathrm{d} l\end{array}$ & 異常者 & $\begin{array}{c}\text { 平均 } \\
\mathrm{mg} / \mathrm{d} l\end{array}$ & 異常者 & $\begin{array}{c}\text { 平均 } \\
\mathrm{mg} / \mathrm{d} l\end{array}$ & 異常者 \\
\hline 183.8 & \begin{tabular}{|c|}
$3 / 14$ \\
$21.4 \%$
\end{tabular} & 122.9 & $\begin{array}{c}3 / 14 \\
21.4 \%\end{array}$ & 47.8 & $\begin{array}{c}4 / 14 \\
28.6 \%\end{array}$ & 97.3 & $\begin{array}{c}2 / 14 \\
14.3 \% \\
\end{array}$ & 5.3 & $\begin{array}{c}1 / 14 \\
7.1 \% \\
\end{array}$ \\
\hline
\end{tabular}


日本総合健診医学会誌

表 5 健康診断の成績と脳出血疾患

\begin{tabular}{|c|c|c|c|c|c|c|c|c|c|}
\hline \multicolumn{2}{|c|}{ 喫 炡 } & \multicolumn{2}{|c|}{ 毎日飲酒 } & \multicolumn{2}{|c|}{ 肥満度 } & \multicolumn{3}{|c|}{ 血 圧 } & \multirow{2}{*}{$\begin{array}{l}\text { 心電应 } \\
\text { 有所見 }\end{array}$} \\
\hline 有 & 本/日 & 有 & g/日 & 平均 & $\begin{array}{r}120 \% \\
\text { 以上 }\end{array}$ & 正常 & 境界 & 高血圧 & \\
\hline $\begin{array}{c}9 / 9 \\
100 \%\end{array}$ & 27.8 & $\begin{array}{c}6 / 9 \\
66.7 \% \\
\end{array}$ & 52 & $115.1 \%$ & $\begin{array}{c}4 / 11 \\
36.4 \% \\
\end{array}$ & \begin{tabular}{|c|}
$2 / 11$ \\
$18.2 \%$ \\
\end{tabular} & $\begin{array}{c}1 / 11 \\
9.1 \% \\
\end{array}$ & $\begin{array}{c}8 / 11 \\
72.3 \% \\
\end{array}$ & $\begin{array}{c}7 / 11 \\
63.6 \% \\
\end{array}$ \\
\hline \multicolumn{2}{|c|}{ 総コレステロール } & \multicolumn{2}{|c|}{ 中性脂肪 } & \multicolumn{2}{|c|}{ HDL-コレステロール } & \multicolumn{2}{|c|}{ 空腹時血糖 } & \multicolumn{2}{|c|}{ 尿 酸 } \\
\hline $\begin{array}{c}\text { 平均 } \\
\mathrm{mg} / \mathrm{d} l\end{array}$ & 異常者 & $\begin{array}{c}\text { 平均 } \\
\mathrm{mg} / \mathrm{d} l\end{array}$ & 異常者 & $\begin{array}{c}\text { 平均 } \\
\mathrm{mg} / \mathrm{d} l\end{array}$ & 異常者 & $\begin{array}{c}\text { 平均 } \\
\mathrm{mg} / \mathrm{d} l\end{array}$ & 異常者 & $\begin{array}{c}\text { 平均 } \\
\mathrm{mg} / \mathrm{d} l\end{array}$ & 異常者 \\
\hline 200.6 & $\begin{array}{c}3 / 11 \\
27.3 \%\end{array}$ & 186.6 & $\begin{array}{c}3 / 11 \\
27.3 \%\end{array}$ & 48.2 & $\begin{array}{c}2 / 11 \\
18.2 \%\end{array}$ & 128.5 & $\begin{array}{c}4 / 11 \\
36.4 \%\end{array}$ & 6.9 & $\begin{array}{c}5 / 11 \\
45.5 \%\end{array}$ \\
\hline
\end{tabular}

\section{2. 健康診断の成績と脳出血疾患}

表 2 , 表 5 は, 健康診断の成績と脳出血疾患との 関係を示したものである。

年齢は, 40 歳から 67 歳で, 40 歳代 2 人, 50 歳 代 5 人, 60 歳代 4 人であった。

喫煙・飲酒状況では，喫煙者は 9 人のうち 9 人 $(100 \%)$ で, 平均 1 日喫煙本数は 27.8 本であった。 飲酒では，毎日飲酒者は 9 人のうち 6 人 $(66.7 \%)$ で, 平均 1 日飲酒量は $52 \mathrm{~g}$ であった。

肥満度は, 平均 $115.1 \%$ で, $120 \%$ 以上の肥満者 は 11 人のうち 4 人 $(36.4 \%)$ であった。

血圧では, 正常血圧者は 11 人のうち 2 人 $(18.2 \%)$, 境界血圧者は 11 人のうち 1 人 $(9.1 \%)$, 高血圧は 11 人のうち 8 人 $(72.7 \%)$ であった。

心電図では，左室肥大をはじめとする有所見者 は 11 人のうち 7 人 $(63.6 \%)$ であった。

血清生化学検査では, 高 TC 值者は 11 人のうち 3 人 $(27.3 \%)$, 高 TG 值者は 11 人のうち 3 人 $(27.3 \%)$ ，低 HDL - C 值者は 11 人のうち 2 人 $(18.2 \%)$, 高 FBS 值者は 11 人のうち 4 人 (36.4 \%)で，この 4 人全員が糖尿病者であり，高 BUA 值者は 11 人のうち 5 人 ( $45.5 \%)$ であった。

\section{考察}

成人病の対策は健康管理の最重要課題である。 このためにも地域においては老人保健法による健 康診断が, 職域においては労働安全法による健康 診断が行われている。

本研究の対象疾患でもある心藏疾患での死亡率 は, 全死亡の $20.5 \%$ で死因順位の第 2 位を, 脳血
管疾患のそれは，13.5\%で第 3 位となっている ${ }^{1)}$

そして，わが国の心臟疾患の代表的存在である 心筋梗塞者は, 人口 10 万人あたり 40 人弱で，イ ギリスの 298.2 人，アメリカの 207.3 人と比較す れば少ないが1,6), 心筋梗塞の危険因子の保有者 は, 人口の高齢化, 食生活をはじめとするライフ スタイルの変化などによって増加しており, 今後, 心筋梗塞の増加が危惧されている7)。

一方, 脳出血疾患は, 近年の治療法の進歩によ って死亡率は隇少しているが，アメリカなどの国 と比較すれば，わが国の死亡率は高率である ${ }^{1,8)}$

悪性新生物は健康診断などによって早期発見・ 早期治療が行われて死亡率は減少しているが, 心 筋梗塞や脳出血疾患に対して, 健康診断はいかな る役割を果しているだろうか。

もちろん, 健康診断は, 疾病の発見も目的の一 つであるが, 健康な人がいつまでも健康を保持・ 増進するための資料として, 健康診断が活用され ることも重要である。

心筋梗塞や脳出血疾患に対しては, 危険因子で もある高血圧症や高脂血症など種々の因子に対す る対策が健康診断を通してこうじられてい る $^{9 \sim 14)}$ 。

しかしながら, 健康診断で異常が認められなく ても, 受診直後に心筋梗塞や脳出血疾患が発症し てくることがあり,このような場合, 健康診断そ のものが問題となる。

そこで, 本研究は, 健康診断受診後 1 年以内に 心筋梗塞や脳出血疾患にて死亡した症例を対象に して, 健康診断の成績と心筋梗塞や脳出血疾患と 
の関係を調べたものである。

職域集団を対象としているため，年齢には上限 がある。心筋梗塞者は, 50 歳代と 60 歳代が主であ り,このことは心筇梗塞が 50 歳代にピークを示す との報告と一致している ${ }^{6,14)}$ 。

心筋梗塞と喫煙との関係では，日本人の $50 〜 60$ 歳代の喫煙率が $50 \%$ 前後であるに対し, 本症例で は $84.9 \%$ と高く，1日喫煙本数も多かった ${ }^{15)}$ 。ま た，毎日飲酒者は $72.7 \%$ ，喫煙と同様に高率で あった ${ }^{16)}$ 。しかし, 血圧は約 6 割の人々が正常で, 安静時の心電図では, ST-T の変化が認められた 人は 14 人のうち 2 人で,他は特に異常が認められ なかったのである。また, TC, TG, HDL-C, FBS, BUA の異常者は, この年代の人々と比較しても 特に高率ではなかった。

心筋梗塞の危険因子としては，喫煙，肥満，高 血圧症, 高コレステロール血症, 低 HDL-C 血症 などの数多くの因子が考えられているが17 24), 本 研究の心筋梗塞死亡症例では, 高血圧, 安静時心 電図での ST-T 異常, 高コレステロール血症, 低 HDL-C 血症, 高血糖, 高尿酸血症などの危険因子 のうち, 危険因子の 4 項目を有する者は 1 人, 2 項 目を有する者は 4 人, 1 項目を有する者は 6 人, 有 しない者は 3 人であったのである。検査值の異常 率は普通で，すべて正常であった症例が少なから ず認められたことは注目すべきであろう。

しかし, 一般の健康診断では行われていない運 動負荷後の心電図では，75\%の人々に異常が認め られたのである。

しかも, 安静時の心電図で ST-T の変化が認め られた 2 例を合わせれば, 14 例のうち, 11 例(78.6 \%）に心電図に変化が認められたことになる。

これらのことを考えると, 心藏疾患, とりわけ 心筋梗塞の発症を予知・予防するためには, 健康 診断の項目に運動負荷心電図の検査が必要と思わ れる。

一方, 脳出血疾患では, 総コレステロール, 中 性脂肪, HDL-コレステロールなどの脂質検査值 はそれほど問題ではなかったが，喫煙は全員に認 められ，高血圧者の割合が $70 \%$ 以上で，心電図の 有所見者, 糖尿病者や高尿酸血症者の割合が非常 に高かった。
高血圧症が脳出血疾患の重大な危険因子であ り, 脳出血疾患に心電図の有所見者が多いとの報 告とも一致している ${ }^{8 \sim 11)}$ 。

しかし，喫煙は脳出血疾患の危険因子であると の報告もあるが，危険因子ではないとの報告も多 い25)。本症例では全員が喫煙者で，しかも，1日本 数が 20 本以上と多かったのである。また, 糖尿病 は脳梗塞の危険因子であるが, 脳出血の危険因子

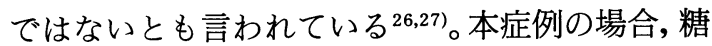
尿病者が多く，この両疾患との間にいかなる関連 があるかは不明である。

ともかく，悪性新生物と異なり，心筋梗塞や脳 出血疾患は突然発症してくる疾病で，このような 疾病を健康診断で予知することは困難なことであ るが，これらの疾病を予防することは，健康診断 の目的なのであるから，年代にあった健康診断項 目を実施するとともに，成人病の危険因子を除く ようなライフスタイルの確立が今後一層求められ るものと思われる。

\section{ま と め}

成人病対策の一つとして, 健康診断が広く行わ れている。

本研究は, 健康診断受診後, 1 年以内に死亡した 心筋梗塞者と脳出血者を対象にして，健康診断の 成績と心筋梗塞と脳出血疾患との関係を調べ, 次 のごとくの結果が得られた。

1. 心筋梗塞者の健康診断の成績では, 喫煙者お よび飲酒者の割合が高率であったが, 肥満度, 血 圧值, 安静時心電図, 血清脂質值（総コレステロ 一ル, 中性脂肪, HDL-コレステロール), 空腹時 血糖値は, 同年代の人の成績と比較して特に変化 なかった。しかし, 運動負荷後の心電図では高率 に異常が認められた。

2. 脳出血者の健康診断の成績では, 喫煙者, 高 血圧者の割合が高率で, さらに, 糖尿病, 高尿酸 血症が高頻度に認められた。

\section{文 献}

1）厚生統計協会：人口動態, 国民衛生の動向, 41：9，42$70,1994$.

2）厚生統計協会：老人保健, 国民衛生の動向, 41:9, 
120-132, 1994.

3）厚生統計協会: 健康診断, 国民衛生の動向, 41:9, 381-383, 1994.

4) 日本消化器集団検診学会全国集計委員会：平成 4 年度 消化器集団検診全国集計, 日消集検誌, 33:2, 200-218, 1995.

5) Report of a WHO Expert Committee: Arterial Hypertension, WHO Technical Report Series, No. 628, WHO, Geneva, 1978.

6) 三浦 傳, 阿部豊彦：心筋梗塞, 日本臨床, $50: 647$, 264-272, 1992.

7）堀部 博, 小林章雄, 赤松康弘, 葉 文 俊：我が国にお ける虚血性心疾患の疫学統計, 日本臨床, $52: 674,3-$ 11, 1994.

8）冨本秀和, 秋口一郎：脳出血, 日本臨床, $50: 647,5-24$, 1992.

9) Kase, C. S. : Intracerebral hemorrhage: Nonhypertensive cases, Stroke, $17:$ 4, 590-595, 1986.

10) Bahemuka, B. : Primary intracerebral hemorrhage and heart weight ; a clinicopathologic case-control review of 218 patients, Stroke, 18:2, 531-536, 1987.

11) 嶋本 喬, 土井光徳, 小町喜男: 脳出血一最近の疫学 的動向, 臨床成人病, 19:1,7-12, 1989.

12）小柳左門：心筋梗塞の発症機序と危険因子, 日本臨床, $52: 674,543-549,1994$.

13) Kannel, W. B. : Habits and coronary heart disease. Th Framingham Heart Study. U. S. Department of health and human services, Public Health Service National Heart Institule Heart Information Center Public Health Service Publication, No. 1515, 1966.

14）広澤弘七郎, 本田 喬, 田中 徹, 楠元雅子：心筋梗塞 の予防と死因分析の統計, 日本臨床, 45:779-788, 1987.

15）厚生統計協会：健康に関連する問題 喫煙, 国民衛生 の動向, $41: 9,98-100,1994$.

16）斎藤征夫：アルコール，健康診断から健康管理へ， 1 版, 29-37, ユリシス, 東京, 1992.

17) Doyle, J. T., Dawber, T. R., Kannel, W. B., Heslin,
A. S., Kahn, H. A. : Cigarette smoking and coro nary heart disease, Combined experience of the Albany and Framingham studies, N. Engl. Med. 266: 19, 796-801, 1962.

18）馬㴊 宏, 宇野欣季, 藤田 一, 梶波康二, 伊藤英章, 武 田三昭, 小林順二, 竹田亮祐：血清脂質, Coronary, 6 ： 3, 257-266, 1986.

19) Fuller, J. H., Shipley, M. J., Rose, G., Jarrett, R. J., Keen, H. : Mortality from coronary heart disease and stroke intelation to degree of glycemia: the Whitehall study, BMJ 287 : 24, 867-870, 1983.

20) Kannel, W. B. : Role of blood pressure in cardiovascular morbidity and mortality, Prog, Cardiorass, Dis. $17: 1,5-24,1974$.

21) Medical research council working party: MRC trial of treatment of mild hypertension: principal results. Br, Med. J., 291: 13, 97-104, 1985.

22) Unsitupa, M., Siitonen, O., Aro, A. and Pyorala, K. J., : Prevalence of coronary heart disease, left ventricular failure and hypertension in middleaged, newly diagnosed Type 2 (non-insulindependent) disbetic suljects, Diabetologia, 28 : 2227, 1985.

23) Ueda, K., Omae, T., Hasuo, Y., Kiyohara, Y., Fujii, I., Wada, J., Kato, I., Kawano, H., Shinkawa, A., Omura, T. and Fujishima, M. : Prognosis and outcome of elderly hypertensives in a Japanese community: results from a long-term prospective study, J. Hypertens, 6 : 12, 991-997, 1988.

24）冷弁田浩司, 橋野達也, 一木和也：冠動脈硬化様式に みた冠危険因子, 日本臨床, $52: 674,35-40,1994$.

25）厚生省：喫煙と脳卒中, 厚生省, 契煙と健康, 136-156, 健康・体力つくり事業財団, 東京, 1988 .

26) Bell, E. T. : A postmortem study of vascular disease in diabetics, Arch, Pathol, 53 : 444-455, 1952.

27) Alex, M., Baron, E. K., Goldenberg, S., Blumenthal, H. T. : An autopsy study of cerevascular accident in diabetes mellitus, Circulation, $25: 663-673,1962$. 